\title{
Effect of Heat Treatment on Catabolites Formation in Relation to Chlorophyll Degradation during Storage of Broccoli (Brassica olearacea L. Italica Group)
} Florets

\author{
Samak Kaewsuksaeng ${ }^{1,2}$, Naoki Yamauchi ${ }^{1,3 *}$, Yoshio Funamoto ${ }^{3}$, Tomohiko Mori ${ }^{1 * *}$,

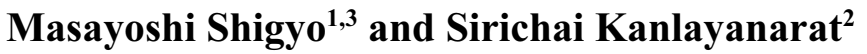 \\ ${ }^{1}$ Faculty of Agriculture, Yamaguchi University, Yoshida, Yamaguchi 753-8515, Japan \\ ${ }^{2}$ Division of Postharvest Technology, School of Bioresources and Technology, King Mongkut's University of Technology Thonburi, \\ Bangkok 10140, Thailand \\ ${ }^{3}$ The United Graduate School of Agricultural Sciences, Tottori University, Koyama-Minami, Tottori 680-8553, Japan
}

The effects of heat treatment on the formation of chlorophyll $(\mathrm{Chl})$ derivatives and Chl-degrading enzyme activities in stored broccoli (Brassica oleracea L. Italica Group 'Ryokutei') florets were determined. The Chl $\boldsymbol{a}$ level barely changed during heat treatment, but each $\mathrm{Chl} a$ derivative level changed. Chlorophyllide (Chlide) $a$, pheophorbide (Pheide) $a, \mathrm{C13}^{2}$-hydroxychlorophyll (C13 $\left.{ }^{2}-\mathrm{OHChl}\right) a, \mathrm{Chl} a^{\prime}$, an isomer of $\mathrm{Chl} a$, and pheophytin (Phy) $a$ were detected as a $\mathrm{Chl}$ derivative during heat treatment and during storage after treatment. Chlide $a$, Pheide $a$, and $\mathrm{C}_{13}{ }^{2}-\mathrm{OHChl} a$ levels decreased during 2-h heat treatment $\left(50^{\circ} \mathrm{C}\right)$, whereas $\mathrm{Chl} a^{\prime}$ and Phy $a$ levels increased. Chldegrading enzyme activities, in particular, Mg-dechelation activity, were effectively suppressed after $2 \mathrm{~h}$ of heat treatment. The content of Chls $a$ and $b$ in control broccoli florets decreased greatly during storage at $15^{\circ} \mathrm{C}$, while the content in heat-treated broccoli florets hardly changed at all. In Chl derivatives, the Pheide $a$ level in broccoli florets treated with or without heat treatment, especially the former, increased appreciably during storage. The Chlide $a$ level in control florets decreased markedly during storage. On the other hand, the Chlide $a$ level in heattreated broccoli florets did not change during storage. Mg-dechelation activity in control florets markedly increased after 4 days of storage at $15^{\circ} \mathrm{C}$, but the enhancement of the activity was suppressed by heat treatment. These findings suggest that $\mathrm{Chl}$ derivatives, especially Pheide $a$, are accumulated as intermediates in heat-treated broccoli florets, and Mg-dechelating action, in conjunction with that of chlorophyllase and Chl-degrading peroxidase, could be involved in $\mathrm{Chl}$ degradation in stored broccoli florets.

Key Words: broccoli, chlorophyll degradation, chlorophyll derivatives, heat treatment.

\section{Introduction}

In general, the yellowing of leaves, florets and fruit pericarp is an important factor indicative of quality deterioration in stored horticultural products. Obviously, in broccoli, the most visible deterioration is the loss of sepal greenness that usually occurs with chlorophyll

Received; January 31, 2007. Accepted; June 6, 2007.

This work was supported in part by a Grant-in-Aid for Scientific Research (No. 17580029) from the Japanese Society for the Promotion Science and the Commission on Higher Education Staff Development Project, the Royal Thai Government.

* Corresponding author (E-mail address: yamauchi@yamaguchiu.ac.jp).

** Present address: Kobeya Bakery Company, Higashiyodogawa-ku, Osaka, Japan.
(Chl) breakdown (Costa et al., 2005; Yamauchi and Watada, 1991, 1993).

An early step in Chl $a$ degradation seems to be removal of the side chain attached to the tetrapyrrole macrocycle to form chlorophyllide (Chlide) $a$ by chlorophyllase. The newly formed Chlide $a$ retains a green color (AmirShapira et al., 1987; Shimokawa et al., 1978). The elimination of $\mathrm{Mg}^{2+}$ from Chlide $a$ to produce pheophorbide (Pheide) $a$ is induced by a Mg-dechelatase (Langmeier et al., 1993) or Mg-dechelating substance (Shioi et al., 1996), and the Pheide $a$ thus loses its green color. Finally, Pheide $a$ is decomposed to fluorescent Chl catabolites, which are primary colorless catabolites, via a red $\mathrm{Chl}$ catabolite by both Pheide $a$ oxygenase and red Chl catabolite reductase (Matile et al., 1999). In this pathway, the conversion of Chlide $a$ to Pheide $a$ could 
be the first step in degreening, and $\mathrm{Mg}$-dechelation activity related to this reaction seems to have an effect on the quality of horticultural produce.

During the past few years, there has been increasing interest in heat-treatment methodologies for the control of insect pests, prevention of fungal rots, and modification of ripening or response to temperature extremes of commodities (Lurie, 1998). Heat treatment is frequently used to maintain the postharvest quality of many horticultural crops (Costa et al., 2005; Funamoto et al., 2002, 2003; Kazami et al., 1991; Lurie, 1998; Terai et al., 1999; Tian et al., 1996). The advantages of postharvest treatments that result in a reduction of the yellowing of broccoli florets and suppression of the activities of Chl-degrading enzymes, such as chlorophyllase and Chl-degrading peroxidase, have been reported (Funamoto et al., 2002, 2003).

In this paper, we evaluate the changes in $\mathrm{Chl}$ derivatives during storage in heat-treated broccoli florets. We also examine the changes of $\mathrm{Chl}$ derivatives and Chl-degrading enzyme activities during heat treatment. Finally, we discuss the physiological role of Chldegrading enzymes, including their action in $\mathrm{Mg}$ dechelation on $\mathrm{Chl}$ degradation in stored broccoli, and the effect of heat treatment on their regulation.

\section{Materials and Methods}

\section{Plant material and preparations}

Fresh broccoli (Brassica olearacea L. Italica Group 'Ryokutei') heads were harvested in Aio, Yamaguchi City and transported to the laboratory of Horticultural Science, Yamaguchi University. The broccoli heads were held in an incubator (MIR-153, Sanyo, Japan) in which hot air $\left(50^{\circ} \mathrm{C}\right)$ was circulated for $2 \mathrm{~h}$. During the treatment, heads were loosely covered with perforated polyethylene bags to reduce weight loss. The heads were kept in polyethylene film bags $(0.03 \mathrm{~mm}$ in thickness) with the top folded over, placed in a corrugated cardboard box $(290 \mathrm{~mm} \times 400 \mathrm{~mm} \times 170 \mathrm{~mm})$, and stored at $15^{\circ} \mathrm{C}$ in the dark. Three replicates of three heads were removed at scheduled intervals during heat treatment and the 6-day period of storage. The floral tissues were analyzed.

\section{Surface color}

The surface color of broccoli florets was determined by measuring the hue angle with a colorimeter (NF 777, Nippon Denshoku, Japan).

\section{Chlorophyll contents and chlorophyll-degrading enzyme assays}

The Chl content in floral tissues was determined using $\mathrm{N}, \mathrm{N}$-dimethylformamide (Moran, 1982).

For enzyme assays, an acetone powder $(500 \mathrm{mg})$ was suspended in $15 \mathrm{~mL}$ of a $10 \mathrm{mM}$ phosphate buffer (pH 7.0) for Chl-degrading peroxidase and in $15 \mathrm{~mL}$ of a $50 \mathrm{mM}$ phosphate buffer (pH 7.0) containing $50 \mathrm{mM}$ $\mathrm{KCl}$ and $0.12 \%$ Triton $\mathrm{X}-100$ for chlorophyllase and
Mg-dechelation activities. A crude enzyme was stirred for $1 \mathrm{~h}$ at $0^{\circ} \mathrm{C}$ and then filtered through Miracloth (Calbiochem, USA). Subsequently, the filtrate was centrifuged at $16000 \times \mathrm{g}$ for $15 \mathrm{~min}$ at $4^{\circ} \mathrm{C}$. The supernatant was used as the crude enzyme extract.

Chlorophyllase activity was determined by modification of the method of Amir-Shapira et al. (1987). The reaction mixture contained $0.5 \mathrm{~mL}$ enzyme solution, $0.1 \mathrm{~mL} 1 \%$ CHAPS, $0.2 \mathrm{~mL} \mathrm{Chl} a$ acetone solution (Chl $a$ $100 \mathrm{mg} \cdot \mathrm{L}^{-1}$ ), and $0.5 \mathrm{~mL}$ of a $0.1 \mathrm{M}$ phosphate buffer $(\mathrm{pH} 7.5)$. The mixture was incubated in water at $25^{\circ} \mathrm{C}$ for $40 \mathrm{~min}$, and the enzyme reaction was stopped by the addition of $4 \mathrm{~mL}$ of acetone. The remaining (nondegraded) Chl $a$ was extracted with $4 \mathrm{~mL}$ of hexane and assayed by reading the absorbance at $663 \mathrm{~nm}$ (U-2001, Hitachi, Japan). The activity was based on the decrease in absorbance by Chl $a$ at $663 \mathrm{~nm}$.

Mg-dechelation activity was determined by modification of the method of Suzuki and Shioi (2002). The reaction mixtures contained a crude enzyme solution $(0.2 \mathrm{~mL}), 98 \mathrm{nM}$ chlorophyllin $a(0.3 \mathrm{~mL})$, and a $50 \mathrm{mM}$ Tris- $\mathrm{HCl}$ buffer $(\mathrm{pH} 8.0)(0.75 \mathrm{~mL})$. Activity was measured at $35^{\circ} \mathrm{C}$ by following the change in $\mathrm{OD}$ at $686 \mathrm{~nm}$. Chlorophyllin $a$ was prepared according to the procedure of Vicentini et al. with slight modifications (1995). Thirty milliliters of a Chl $a$ acetone solution was partitioned into $20 \mathrm{~mL}$ petroleum ether. The ether phase was separated, washed three times with $20 \mathrm{~mL}$ distilled water, and mixed with $1 \mu \mathrm{L}$ of $30 \%(\mathrm{w} / \mathrm{v}) \mathrm{KOH}$ in methanol per $30 \mu \mathrm{g} \mathrm{Chl} a$ to form chlorophyllin $a$. The solution in which chlorophyllin $a$ was allowed to precipitate was centrifuged at $16000 \times \mathrm{g}$ at $4^{\circ} \mathrm{C}$ for $10 \mathrm{~min}$. The precipitate was dissolved in distilled water and brought to $\mathrm{pH} 9$ by adding $2 \mathrm{M}$ Tricine.

Chl-degrading peroxidase was determined as described elsewhere (Yamauchi et al., 1997). The reaction mixture contained $0.5 \mathrm{~mL}$ enzyme solution, $0.1 \mathrm{~mL} 1.0 \%$ Triton X-100, $0.1 \mathrm{~mL} 5.0 \mathrm{mM}$-coumaric acid, $0.1 \mathrm{~mL} 0.3 \%$ hydrogen peroxide, $0.2 \mathrm{~mL}$ Chl $a$ acetone solution (Chl $\left.a-100 \mathrm{mg} \cdot \mathrm{L}^{-1}\right)$, and $1.5 \mathrm{~mL} 0.1 \mathrm{M}$ phosphate buffer (pH 5.5). Activity was determined spectrophotometrically by measuring the decrease of $\mathrm{Chl} a$ at $668 \mathrm{~nm}$ at $25^{\circ} \mathrm{C}$.

One unit of chlorophyllase and Chl-degrading peroxidase was defined as a change of $1.0 \mu \mathrm{g} \mathrm{Chl} a$ degradation per min. Mg-dechelation activity was expressed as increased absorbance at $686 \mathrm{~nm}$ per min. The enzyme protein content was assayed by the method of Bradford (1976).

\section{Analyses of chlorophyll and its derivatives Pigment extraction}

Broccoli florets $(2 \mathrm{~g})$ were homogenized in $9 \mathrm{~mL}$ of acetone-HEPES, which was prepared from $16 \mathrm{~mL}$ of cold acetone and $2 \mathrm{~mL}$ of a $50 \mathrm{mM}$ HEPES buffer $(\mathrm{pH} 7.5)$, and the remaining solution $(9 \mathrm{~mL}$ of acetoneHEPES) was then added. The extraction was continually 
operated in the dark for $5 \mathrm{~min}$. Subsequently, the aliquots were filtered through a DISMIC filter $(0.45 \mu \mathrm{m}$, ADVANTEC, Japan) and used for HPLC analyses.

Preparation of chlorophyll and it derivatives

Chls were extracted from spinach (Spinacia oleracea L.), and Chls $a$ and $b$ were partially purified by adding 1,4 dioxane and distilled water to the acetone extract. The mixture was then allowed to stand until a precipitate formed. The mixture was then centrifuged at $15000 \times \mathrm{g}$ for $10 \mathrm{~min}$, and the pellet was dissolved in $10 \mathrm{~mL}$ petroleum ether. Individual pigments were purified from the petroleum ether extract for use as a standard. Chls $a$ and $b$ were separated by sucrose column chromatography according to the method of Perkins and Roberts (1962).

Chlide $a$ was prepared from $\mathrm{Chl} a$ by an enzymatic reaction using a chlorophyllase extracted from acetone powder of Chenopodium album, which has high chlorophyllase activity (Shioi et al., 1996). Pheophytin (Phy) $a$ was prepared by adding one drop of $2 \mathrm{~N} \mathrm{HCl}$ to $\mathrm{Chl} a$ acetone solution. $\mathrm{C}^{2} 3^{2}$-hydroxychlorophyll $\left(\mathrm{C}^{2} 3^{2}\right.$ OHChl) $a$, a derivative of $\mathrm{Chl} a$ oxidized at position $13^{2}$, was prepared by adding peroxidase (horseradish, Sigma-Aldrich, USA) with the existence of $\mathrm{H}_{2} \mathrm{O}_{2}$ and $p$-coumaric acid to Chl $a$ solution. Chl $a^{\prime}$, an isomer of $\mathrm{Chl} a$, was prepared by boiling the purified $\mathrm{Chl}$ acetone solution for $15 \mathrm{~min}$.

Pheide $a$ was purchased from Wako Pure Chemical Industries (Tokyo, Japan), and pyropheophorbide $a$ was purchased from Tama Biochemical (Tokyo, Japan). The absorption spectrum and the retention time of each $\mathrm{Chl}$ and its derivative were measured and used as a standard. HPLC analysis

$\mathrm{Chl}$ and its derivatives were analyzed by HPLC using a Hitachi L-7100 pump with an automated gradient controller and a Hitachi L-2450 diode array detector or a Hitachi L-7420 UV-Visible spectrophotometer. The absorption spectrum of the pigment was recorded at $665 \mathrm{~nm}$. Pigments were separated on a LiChrospher C18 column (MERCK), $4 \times 250 \mathrm{~mm}$, using two solvents: A, methanol : water $(80: 20, \mathrm{v} / \mathrm{v})$ and $\mathrm{B}$, ethyl acetate in a gradient. Solvent $\mathrm{B}$ was added to solvent $\mathrm{A}$ at a linear rate until a 50:50 mixture was attained at the end of $20 \mathrm{~min}$. The $50: 50$ mixture was then used isocratically for an additional $20 \mathrm{~min}$, as described by Eskin and Harris (1981). The flow rate was $1 \mathrm{~mL} \cdot \mathrm{min}^{-1}$, and the injection volume was $100 \mu \mathrm{L}$. The identification of $\mathrm{Chl}$ and its derivatives was based on the retention time and the visible absorption spectra.

\section{Results}

Changes in chlorophyll derivatives during heat treatment

The Chl $a$ level barely changed during heat treatment, but each Chl $a$ derivative level changed. The HPLC chromatogram of $\mathrm{Chl}$ derivatives extracted from broccoli florets demonstrated sequential elution of Chlide $a$, Pheide $a, \mathrm{C}^{2} 3^{2}-\mathrm{OHChl} a, \mathrm{Chl} a$, and Phy $a$ during heat treatment (Fig. 1). Chlide $a$, Pheide $a, \mathrm{C} 13^{2}-\mathrm{OHChl} a$, and Phy $a$ were present in fresh broccoli florets. Chlide $a$ level increased after $1 \mathrm{~h}$ of heat treatment at $50^{\circ} \mathrm{C}$ and then greatly decreased. Pheide $a$ and $\mathrm{C}^{2} 3^{2}-\mathrm{OHChl} a$ levels decreased during heat treatment, whereas the $\mathrm{Chl} a^{\prime}$ level increased during 2-h heat treatment. Phy $a$ level also increased during heat treatment.

\section{Changes in chlorophyll-degrading enzyme during heat treatment}

As seen in Figures $2 \mathrm{~A}$ and $2 \mathrm{~B}$, chlorophyllase and $\mathrm{Mg}$-dechelation activities in broccoli florets increased after $1 \mathrm{~h}$ of heat treatment, and, later, those activities decreased by $9 \%$ and $20 \%$, respectively. On the other hand, Chl-degrading peroxidase activity dropped gradually to $77 \%$ during heat treatment (Fig. 2C).

\section{Changes in surface color and chlorophyll content during storage}

Broccoli florets without heat treatment (control) remained green for 3 days of storage at $15^{\circ} \mathrm{C}$ and turned yellow on day 4 . In comparison, heat-treated broccoli florets remained green through 6 days of storage. Hue angle values in the control declined gradually during storage at $15^{\circ} \mathrm{C}$ and then decreased significantly after day 6 , in contrast to those of heat-treated broccoli florets, which changed little during storage (Fig. 3). Chls $a$ and $b$

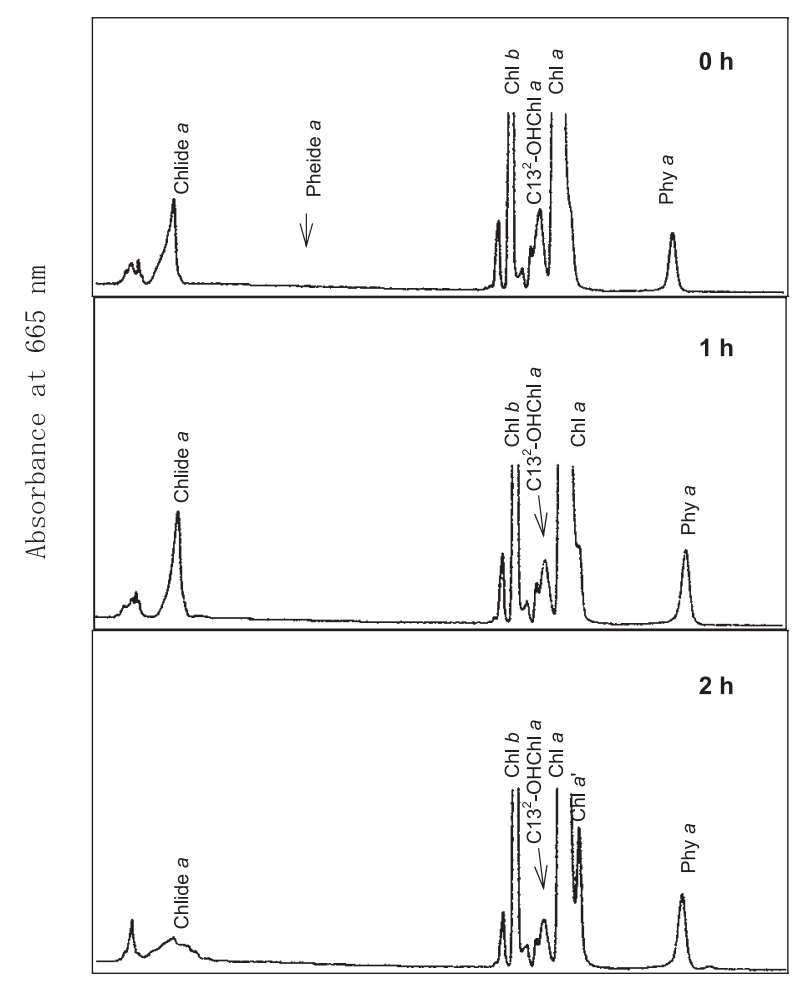

Fig. 1. Changes in HPLC chromatogram of chlorophyll and its derivatives of broccoli florets during heat treatment. Broccoli heads were held in hot air at $50^{\circ} \mathrm{C}$ for $2 \mathrm{~h}$. Chl-Chlorophyll, Chlide-Chlorophyllide, Pheide-Pheophorbide, $\mathrm{C13}^{2}$ $\mathrm{OHChl}-\mathrm{C} 13^{2}$-hydroxychlorophyll, Phy-Pheophytin, Chl $a^{\prime}-$ an isomer of $\mathrm{Chl} a$. 

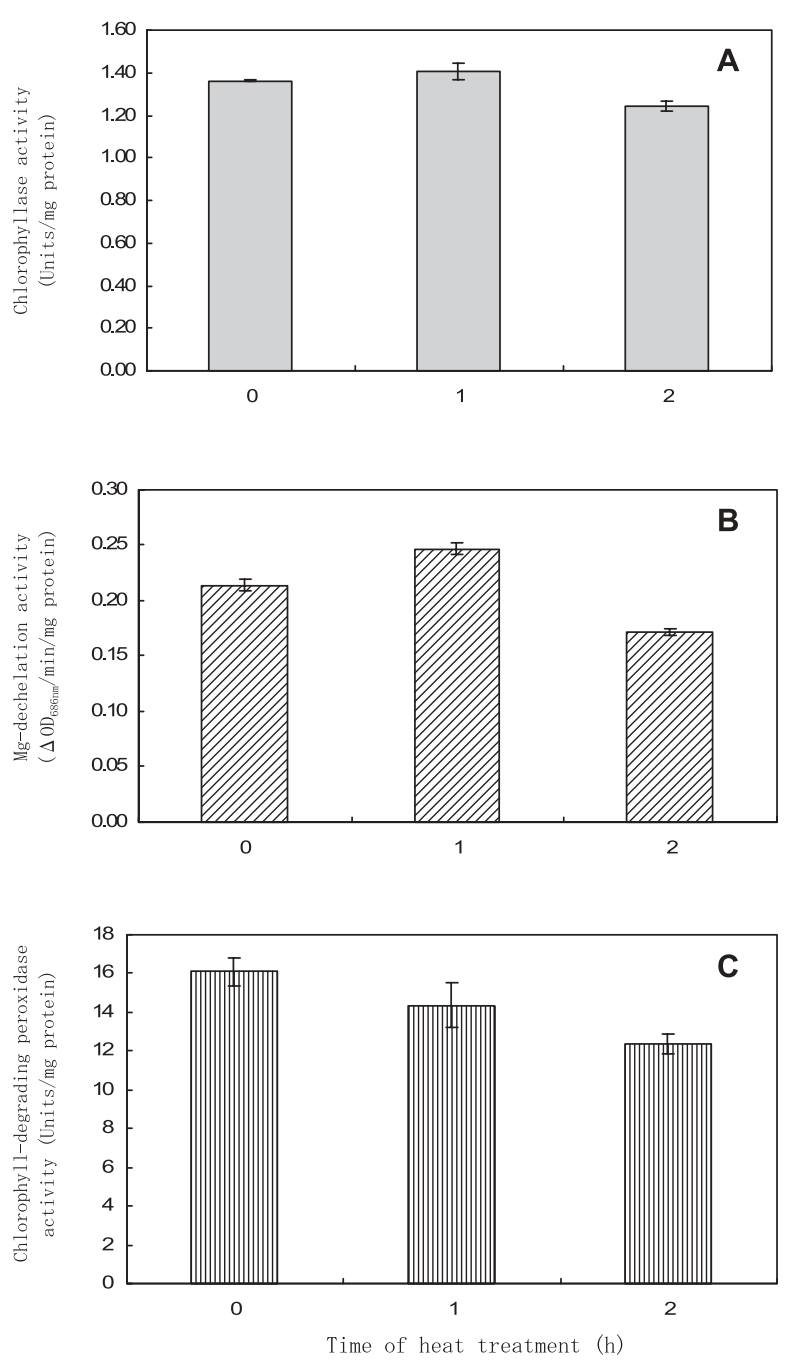

Fig. 2. Changes in chlorophyllase (A), Mg-dechelation activity (B) and chlorophyll-degrading peroxidase (C) of broccoli florets during heat treatment. Broccoli heads were held in hot air at $50^{\circ} \mathrm{C}$ for $2 \mathrm{~h}$. Vertical bars represent average values with $\pm \mathrm{SD}$ $(\mathrm{n}=3)$.

contents in broccoli florets in the control decreased by $75 \%$ and $88 \%$ after 6 days of storage at $15^{\circ} \mathrm{C}$, respectively, whereas the contents in heat-treated broccoli florets change little in the first 3 days of storage at $15^{\circ} \mathrm{C}$ and then decreased slightly (Fig. 4).

\section{Changes in chlorophyll derivatives during storage}

Chlide $a$, Pheide $a, \mathrm{C}_{1} 3^{2}-\mathrm{OHChl} a$, and Phy $a$ were mainly detected as $\mathrm{Chl}$ derivatives during storage at $15^{\circ} \mathrm{C}$. The Chlide $a$ level in the control decreased markedly during storage at $15^{\circ} \mathrm{C}$ and was barely observable on day 6 , whereas that in heat-treated broccoli florets did not change during storage (Fig. 5A). The Pheide $a$ level in broccoli florets with or without heat treatment increased during storage at $15^{\circ} \mathrm{C}$, and the level in heat-treated broccoli florets was higher than that in the control during storage (Fig. 5B).

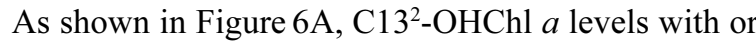

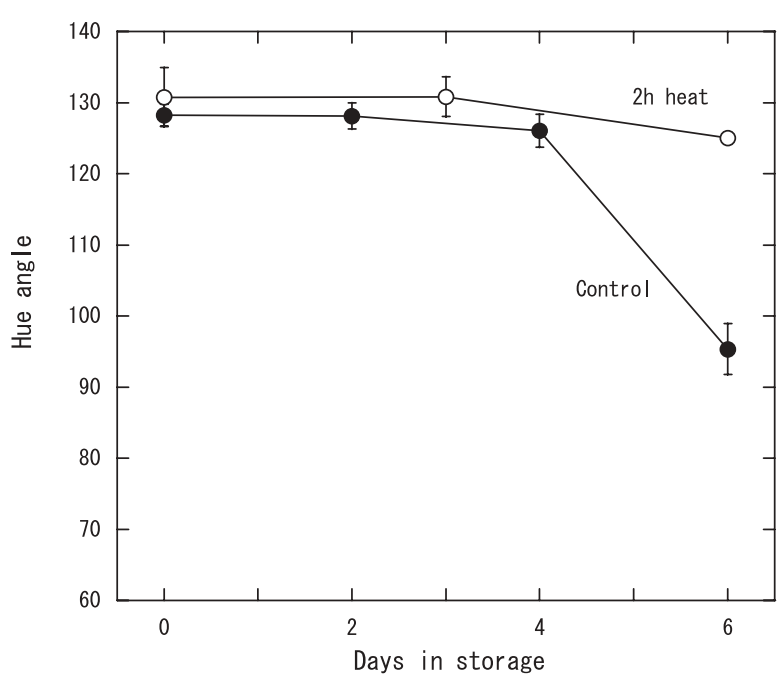

Fig. 3. Changes in hue angle of broccoli florets with or without heat treatment during storage at $15^{\circ} \mathrm{C}$. Broccoli heads were held in hot air at $50^{\circ} \mathrm{C}$ for $2 \mathrm{~h}$, followed by storage. Vertical bars represent average values with $\pm S D(n=3)$.

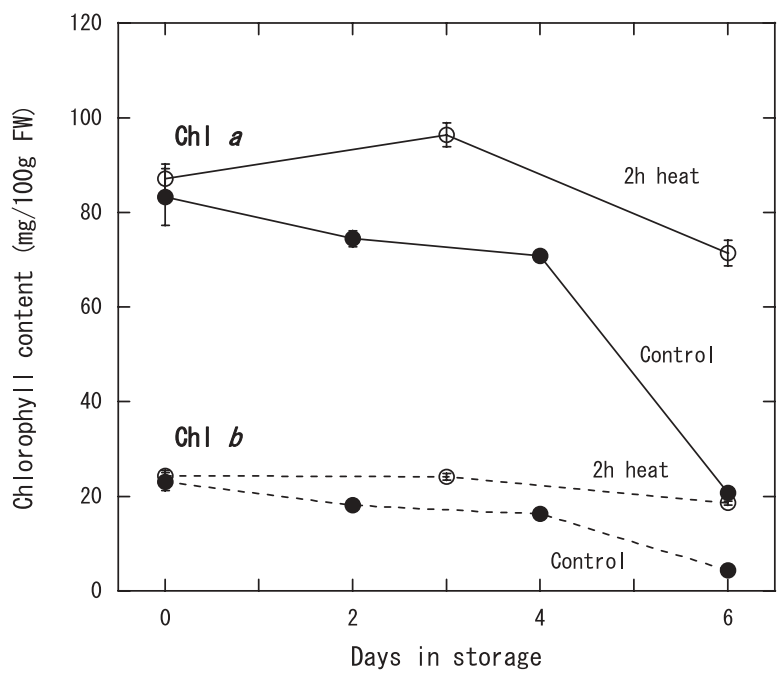

Fig. 4. Changes in chlorophylls contents of broccoli florets with or without heat treatment during storage at $15^{\circ} \mathrm{C}$. Broccoli heads were held in hot air at $50^{\circ} \mathrm{C}$ for $2 \mathrm{~h}$, followed by storage. Vertical bars represent average values with $\pm \mathrm{SD}(\mathrm{n}=3)$. ChlChlorophyll.

without treatment decreased greatly during storage. The Phy $a$ level in broccoli florets with or without heat treatment increased slightly for the first 3 or 4 days of storage at $15^{\circ} \mathrm{C}$ and then decreased sharply (Fig. 6B). Furthermore, Chl $a^{\prime}$ levels with or without treatment did not show a constant pattern during storage.

\section{Changes in Mg-dechelation activity during storage}

Mg-dechelation activity in broccoli florets, as is apparent in Figure 7, was efficiently suppressed during heat treatment, and the activity in heat-treated broccoli increased slightly during storage. On the other hand, activity in the control increased 2 days after storage at 

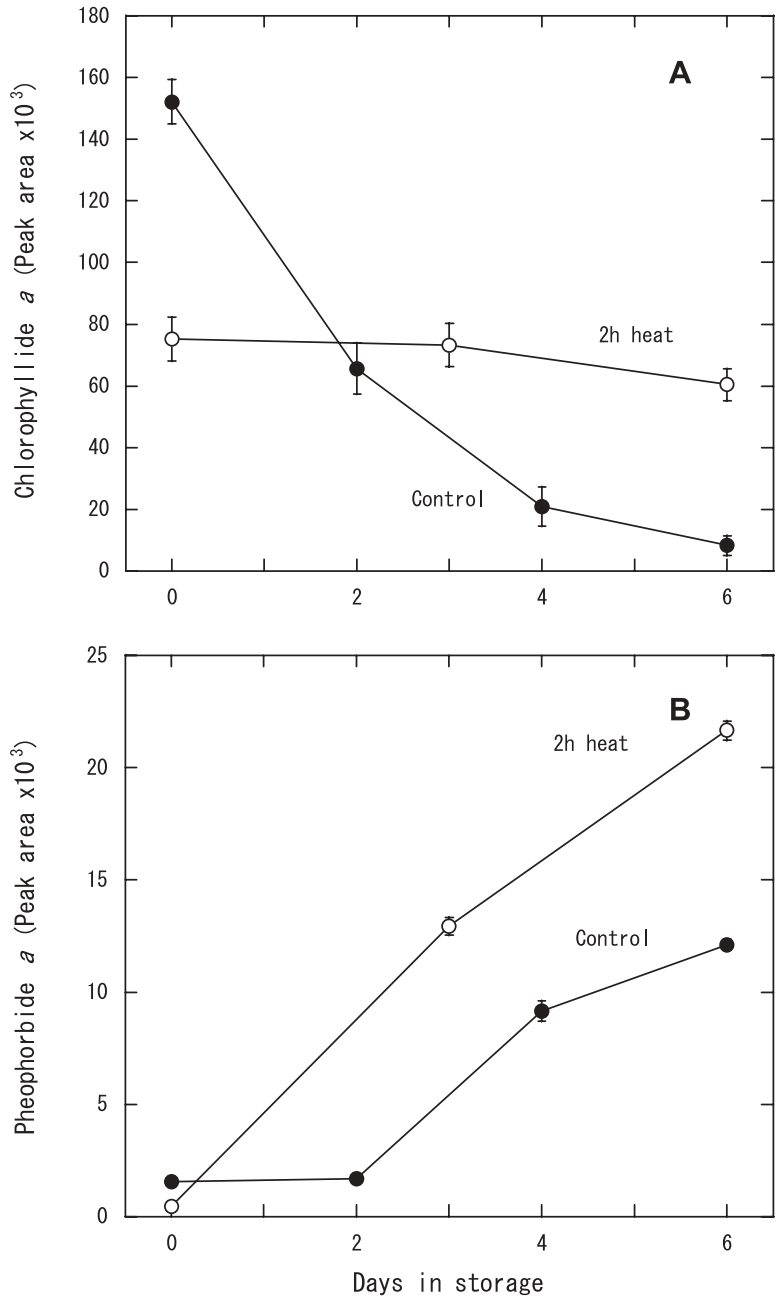

Fig. 5. Changes in chlorophyllide $a(\mathrm{~A})$ and pheophorbide $a(\mathrm{~B})$ levels of broccoli florets with or without heat treatment during storage at $15^{\circ} \mathrm{C}$. Broccoli heads were held in hot air at $50^{\circ} \mathrm{C}$ for $2 \mathrm{~h}$, followed by storage. Vertical bars represent average values with $\pm \mathrm{SD}(\mathrm{n}=3)$.

$15^{\circ} \mathrm{C}$. In heat-treated broccoli florets, Mg-dechelation activity was lower than that in the control during storage.

\section{Discussion}

With regard to the quantitative changes of $\mathrm{Chl}$ derivatives during heat treatment, the Chlide $a$ level decreased significantly in heat-treated broccoli florets for $2 \mathrm{~h}$ following a temporary increase of Chlide $a$. The Pheide $a$ level was only slightly observable in fresh broccoli florets and hardly detectable during heat treatment. Moreover, chlorophyllase and Mg-dechelation activities increased after $1 \mathrm{~h}$ of heat treatment. These findings suggest that the Chl degradation pathway, which is related to chlorophyllase and $\mathrm{Mg}$-dechelation, might be temporally activated by heat treatment. The $\mathrm{C} 13^{2}-$ OHChl $a$ level declined during heat treatment with a concomitant decrease of Chl-degrading peroxidase activity. We reported in a previous paper (Funamoto et al., 2002) that heat treatment at $50^{\circ} \mathrm{C}$ for $2 \mathrm{~h}$ could reduce
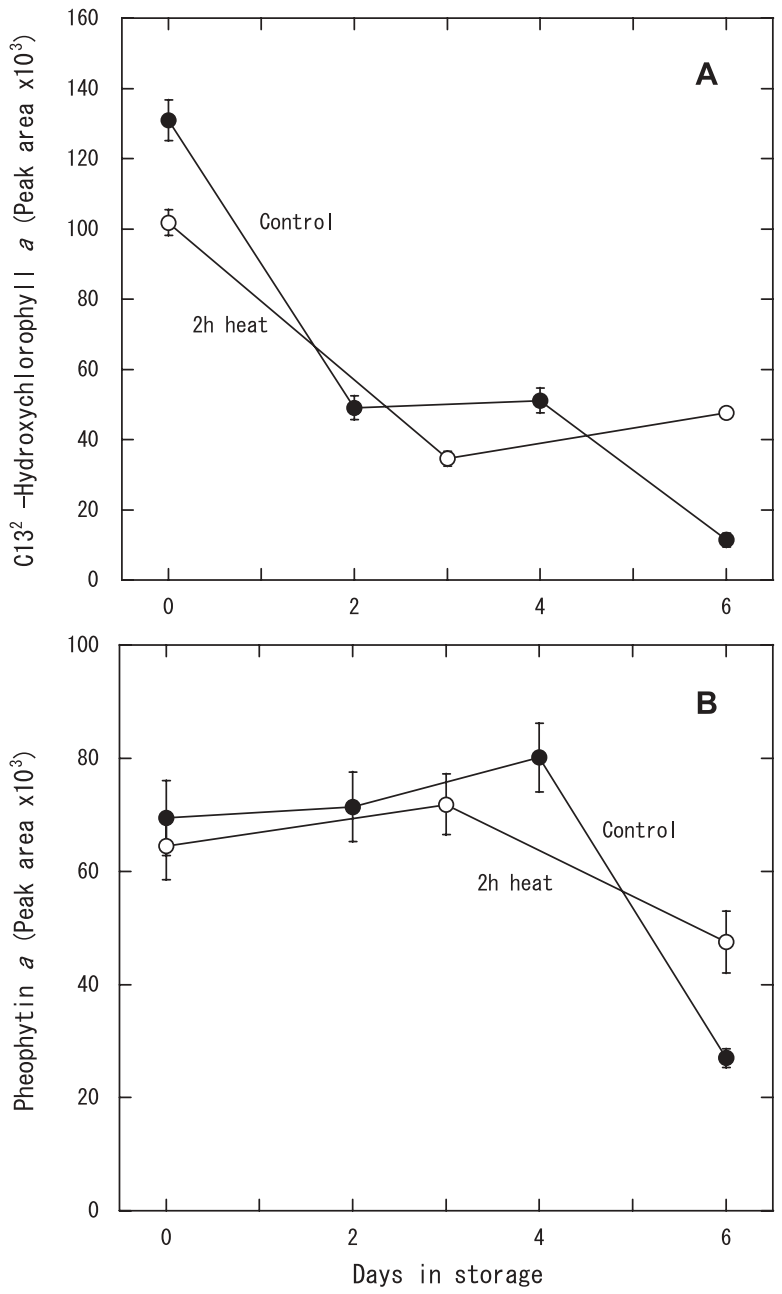

Fig. 6. Changes in $\mathrm{C}^{2} 3^{2}$-hydroxychlorophyll $a(\mathrm{~A})$ and pheophytin $a$ (B) levels of broccoli florets with or without heat treatment during storage at $15^{\circ} \mathrm{C}$. Broccoli heads were held in hot air at $50^{\circ} \mathrm{C}$ for $2 \mathrm{~h}$, followed by storage. Vertical bars represent average values with $\pm \operatorname{SD}(\mathrm{n}=3)$.

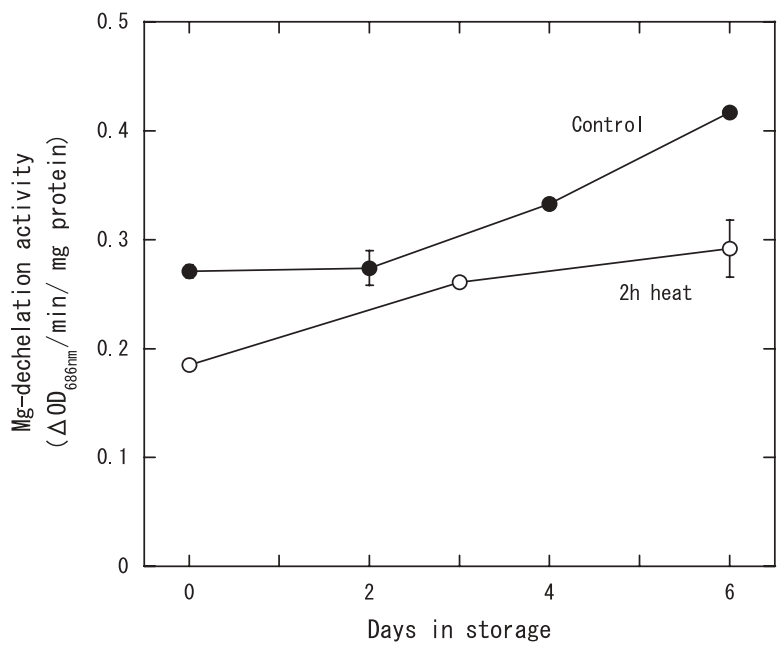

Fig. 7. Mg-dechelation activity of broccoli florets with or without heat treatment during storage at $15^{\circ} \mathrm{C}$. Broccoli heads were held in hot air at $50^{\circ} \mathrm{C}$ for $2 \mathrm{~h}$, followed by storage. Vertical bars represent average values with $\pm \operatorname{SD}(n=3)$. 
Chl degradation due to suppression of the activities of Chl-degrading enzymes, such as chlorophyllase and Chldegrading peroxidase, during storage. In this study, the inhibitory effect of $\mathrm{Chl}$ degradation seems to be related to the activities of Chl-degrading enzymes, chlorophyllase, Mg-dechelation, and Chl-degrading peroxidase, which decrease during heat treatment and continue to be suppressed during storage. In addition, as noted previously (Funamoto et al., 2002), $1 \mathrm{~h}$ heat treatment was insufficient to inhibit $\mathrm{Chl}$ degradation in stored broccoli florets, which suggests that Chl-degrading enzyme activities are not suppressed during heat treatment for $1 \mathrm{~h}$.

Heat treatment of broccoli florets has been reported to effectively suppress $\mathrm{Chl}$ degradation during storage (Costa et al., 2005; Funamoto et al., 2002; Kazumi et al., 1991; Terai et al., 1999; Tian et al., 1996). In this study, the green color of heat-treated broccoli florets lasted longer than that in the control; however, the formation of Pheide $a$ occurred continuously in heattreated broccoli florets, suggesting that Pheide $a$ might be accumulated as an intermediate of Chl degradation by the inhibition of Pheide $a$ oxygenase and $\mathrm{Mg}$ dechelation activities, especially the former. All Chl derivatives, except Pheide $a$, showed a slight decline in heat-treated broccoli florets during storage. In contrast, in the control, Chl $a$ was promptly degraded without the accumulation of Chl $a$ derivatives, except for Pheide $a$. Pheide $a$ in the control also accumulated after 2 days of storage, but the accumulation was lower than that in heat-treated broccoli florets, as shown in Figure 5B. These results demonstrate that heat treatment could effectively suppress Chl degradation owing to inhibition of the action of Chl-degrading enzymes including $\mathrm{Mg}$ dechelation activity.

$\mathrm{Mg}$-dechelation activity was enhansed during the senescence of radish cotyledons (Suzuki et al., 2005), ripening of strawberry fruit (Costa et al., 2002), and yellowing of Ginkgo biloba leaves (Tang et al., 2000). In this study, Mg-dechelation activity in the control increased appreciably during storage at $15^{\circ} \mathrm{C}$. The activity in heat-treated broccoli florets increased slightly during storage, but the increase of the activity was lower than that in the control. Also, we demonstrated that $\mathrm{Mg}$ dechelation activity was more markedly inhibited during heat treatment than that of other Chl-degrading enzymes, which could suggest that Mg-dechelation activity is significantly involved in the Chl-degrading process. In addition, Chlide $a$ levels in heat-treated broccoli florets were not accumulated during storage in spite of the inhibition of $\mathrm{Mg}$-dechelation activity, inferring that Chldegrading peroxidase might relate in part to the oxidation of Chlide $a$ as well as Chl $a$ (Huff, 1982).

Chlide $a$, which is formed from Chl $a$ by chlorophyllase (Amir-Shapira et al., 1987; Shimokawa et al., 1978), is degraded to Pheide $a$ by releasing $\mathrm{Mg}^{2+}$. Mg-dechelatase (Langmeier et al., 1993) or Mg- dechelating substance, a heat-stable substance with a low-molecular mass (Shioi et al., 1996), is reported to be involved in this reaction. Costa et al. (2002) also indicated that $\mathrm{Mg}$-dechelating activity in strawberry fruit was present in a low-molecular-mass compound sensitive to proteinase and $\mathrm{Hg}^{2+}$, suggesting that the $\mathrm{Mg}$ dechelating substance is a polypeptide containing the SH group. Further study is needed to clarify the characterization of the Mg-dechelating substance in broccoli florets.

In conclusion, Chl derivatives, especially Pheide $a$, are accumulated as intermediates of $\mathrm{Chl}$ degradation in heat-treat broccoli florets. In contrast, in control florets, Chl $a$ was promptly degraded to colorless, low-molecular weight compounds without the accumulation of $\mathrm{Chl}$ derivatives except for Pheide $a$. Additionally, $\mathrm{Mg}$ dechelating action, together with chlorophyllase and Chldegrading peroxidase, is related to Chl degradation in stored broccoli florets. The inhibition of $\mathrm{Chl}$ degradation by heat treatment seems to be partly due to the suppression of these enzyme activities.

\section{Literature Cited}

Amir-Shapira, D., E. E. Goldschmidt and A. Altman. 1987. Chlorophyll catabolism in senescing plant tissues: in vivo breakdown intermediates suggest different degradative pathways for citrus fruit and parsley leaves. Proc. Natl. Acad. Sci. USA 84: 1901-1905.

Bradford, M. M. 1976. A rapid and sensitive method for the quantitation of microgram quantities of protein utilizing the principle of protein-dye binding. Anal. Biochem. 72: 248-254.

Costa, M. L., P. M. Civello, A. R. Chaves and G. A. Martínez. 2002. Characterization of Mg-dechelatase activity obtained from Fragaria x ananassa fruit. Plant Physiol. Biochem. 40: 111-118.

Costa, M. L., P. M. Civello, A. R. Chaves and G. A. Martínez. 2005. Effect of hot air treatments on senescence and quality parameters of harvested broccoli (Brassica oleracea L var Italica) heads. J. Sci. Food Agric. 85: 1154-1160.

Eskin, K. and L. Harris. 1981. High-performance liquid chromatography of etioplast pigments in red kidney bean leaves. Photochem. Photobiol. 33: 131-133.

Funamoto, Y., N. Yamauchi, T. Shigenaga and M. Shigyo. 2002. Effects of heat treatment on chlorophyll degrading enzymes in stored broccoli (Brassica olearacea L.). Postharvest Biol. Technol. 24: 163-170.

Funamoto, Y., N. Yamauchi and M. Shigyo. 2003. Involvement of peroxidase in chlorophyll degradation in stored broccoli (Brassica olearacea L.) and inhibition of activity by heat treatment. Postharvest Biol. Technol. 28: 39-46.

Huff, A. 1982. Peroxidase-catalysed oxidation of chlorophyll by hydrogen peroxide. Phytochemistry 21: 261-265.

Kazumi, D., T. Sato, H. Nakagawa and N. Ogura. 1991. Effect of pre-storage hot water dipping of broccoli heads on shelf life and quality during storage. Nippon Nogeikagaku Kaishi. 65: 19-26 (In Japanese with English abstract).

Langmeier, M., S. Ginsburg and P. Matile. 1993. Chlorophyll breakdown in senescent leaves: demonstration of $\mathrm{Mg}$ dechelatase activity. Physiol. Plant. 89: 347-353.

Lurie, S., 1998. Postharvest heat treatments. Postharvest Biol. Technol. 14: 257-269. 
Matile, P., S. Hörtensteiner and H. Thomas. 1999. Chlorophyll degradation, Annu. Rev. Plant Physiol. Plant Mol. Biol. 50: 69-75.

Moran, R. 1982. Formulae for determination of chlorophyllous pigments extracted with $N, N$-dimethylformamide. Plant Physiol. 69: 1376-1381.

Perkins, H. J. and D. W. Roberts. 1962. Purification of chlorophylls, pheophytins and pheophorbides for specific activity determinations. Biochim. Biophys. Acta. 58: 486498.

Shimokawa, K., S. Shimada and K. Yaeo. 1978. Ethyleneenhanced chlorophyllase activity during degreening of Citrus unshiu Marc. Sci. Hort. 8: 129-135.

Shioi, Y., N. Tomita, T. Tsuchiya and K. Takamiya. 1996. Conversion of chlorophyllide to pheophorbide by $\mathrm{Mg}$ dechelating substance in extracts of Chenopodium album. Plant Physiol. Biochem. 34: 41-47.

Suzuki, T., T. Kunieda, F. Murai, S. Morioka and Y. Shioi. 2005. $\mathrm{Mg}$-dechelation activity in radish cotyledons with artificial and native substrates, Mg-chlorophyllin $a$ and chlorophyllide a. Plant Physiol. Biochem. 43: 459-464.

Suzuki, T. and Y. Shioi. 2002. Re-examination of Mg-dechelation reaction in the degradation of chlorophylls using chlorophyllin $a$ as a substrate. Photosynth. Res. 74: 217-223.

Tang, L., A. Okazawa, E. Fukusaki and A. Kobayashi. 2000.
Removal of magnesium by Mg-dechelatase is a major step in chlorophyll degrading pathway in Ginkgo biloba in the process of autumnal tints. Z. Naturforsch. 55: 923-926.

Terai, H., M. Kanou, M. Mizuno and H. Tsuchida. 1999. Inhibition of yellowing and ethylene production in broccoli florets following high temperature treatment with hot air. Food Preser. Sci. 25: 221-227.

Tian, M. S., A. B. Woolf, J. H. Bowen and I. B. Ferguson. 1996. Changes in color and chlorophyll fluorescence of broccoli florets following hot water treatment. J. Amer. Soc. Hort. Sci. 121: 310-313.

Vicentini, F., F. Iten and P. Matile. 1995. Development of assay for Mg-dechelatase of oilseed rape cotyledons, using chlorophyllin as substrate. Physiol. Plant. 94: 57-63.

Yamauchi, N. and A. E. Watada. 1991. Regulated chlorophyll degradation in spinach leaves during storage. J. Amer. Soc. Hort. Sci. 116: 58-62.

Yamauchi, N. and A. E. Watada. 1993. Pigment changes in parsley leaves during storage in controlled or ethylene containing atmosphere. J. Food. Sci. 58: 104-108.

Yamauchi, N., X. Xia and F. Hashinaga. 1997. Involvement of flavanoid oxidation with chlorophyll degradation by peroxidase in wase Satsuma mandarin fruits. J. Japan. Soc. Hort. Sci. 66: 263-288. 